THE INDIAN SLAVE TRADE 



\section{THE INDIAN SLAVE TRADE THE RISE OF}

THE ENGLISH EMPIRE IN THE AMERICAN SOUTH, 1670-1717

\section{ALAN GALLAY}




\section{Copyright (C) 2002 by Yale University.}

All rights reserved.

This book may not be reproduced, in whole or in part, including illustrations, in any form (beyond that copying permitted by Sections 107 and 108 of the U.S. Copyright Law and except by reviewers for the public press), without written permission from the publishers.

\section{Designed by Mary Valencia.}

Set in Garamond and Trajan types by Integrated Publishing Solutions, Grand Rapids, Michigan.

Printed in the United States of America by Vail-Ballou Press, Binghamton, New York.

\section{Library of Congress Cataloging-in-Publication Data \\ Gallay, Alan.}

The Indian slave trade : the rise of the English empire in the American south, 1670-1717 / Alan Gallay.

$$
\text { p. } \quad \mathrm{cm} \text {. }
$$

Includes bibliographical references and index.

ISBN 0-300-08754-3 (alk. paper)

1. Slave trade-Great Britain-History-17th century. 2. Slave trade-Southern StatesHistory - 17th century. 3. Indian slaves—Southern States—History—17th century. 4. Indians, Treatment of-Southern States—History—17th century. 5. Indians of North America—Southern States-Social conditions. I. Title.

$$
\begin{gathered}
\text { HT1162.G35 } 2002 \\
381^{\prime} .44^{\prime} 0975-\mathrm{dc} 21 \\
2001005270
\end{gathered}
$$

A catalogue record for this book is available from the British Library.

The paper in this book meets the guidelines for permanence and durability of the Committee on Production Guidelines for Book Longevity of the Council on Library Resources. 
FOR

CYRANA 
he savage who told me all of this is a man of the Maugoulacho nation who is living with the Mauvilla nation. He had assured me that

1 the English were in those nations every day, and that they take pack horses burdened with clothing, guns, gunpowder, shot, and a quantity of other goods which are sold or traded to the savages for cured deer hides, for fresh deer hides with hair, and for the buffalo that are covered in a fine wool being gray in color like a mouse. But the greatest traffic between the English and the savages is the trade of slaves which the nations take from their neighbors whom they war with continuously, such that the men take the women and children away and sell them to the English, each person being traded for a gun. This greatly destroys the nations which are our neighbors.

—Charles Levasser, 1700 